Mu 'jizatullah

\title{
IMPLEMENTASI PENDIDIKAN AGAMA DAN KEAGAMAAN PASCA KONFLIK DI PAPUA
}

\author{
Oleh: Mu'jizatullah
}

\begin{abstract}
Abstrak
This research aims to describe the implication of social conflict to education of religion (formal and informal) implementation. This was conducted at Abepura, Papua. Data was collected by depth interview and observation.

In Papua, conflict was caused by ethnical problem and social distance between local and comer. This conflict relatively didn't influence learning activity. Local government always give more attention to school in Рариа.
\end{abstract}

Key word: conflict, implementation, education, religion.

\section{PENDAHULUAN}

$\mathrm{P}$ erkembangan masyarakat saat ini menghendaki adanya pembinaan yang seimbang antara nilai agama dan sikap, pengetahuan, kecerdasan dan keterampilan, kemampuan berkomunikasi dengan masyarakat secara luas serta meningkatkan kesadaran pentingnya pendidikan agama dan keagamaan.

Salah satu strategi yang harus dikembangkan adalah menghilangkan konflik prasangka atau stereotif-stereotif mengenai umat beragama satu sama lain. Dengan meningkatkan sikap saling menghargai, toleransi antar umat beragama melalui sistem pendidikan multikultur, dengan cara memberikan kesempatan bagi murid dan guru dari berbagai latar belakang agama untuk berinteraksi secara setara dan saling menghargai. (Henry Lgates, 2003 :123) 


\section{Mn 'jizatullah}

Hal ini penting dilakukan mengingat Provinsi Papua merupakan miniatur gambaran dari Indonesia. Penduduknyaterdiri dari multikulturdan etnis. Sebagai upaya untuk mencegah konflik antaragama dan etnis. Diperlukan pengembangan pendidikan agama dan keagamaan dengan memberikan sarana yang menjadi media dalam upaya aplikasi tujuan tersebut. Sarana dan tujuan itu adalah terwujud dalam sekolah. Peranan pendidikan agama demikian pula pendidikan keagamaan cukup besar peranannya sebagai sarana dakwah atau tenaga-tenaga kerja profesional yang mengerti akan tugas dan kewajibannya serta memiliki kapabilitas dalam menunaikan tugasnya.

Berdasarkan latar belakang maka permasalahan dalam penelitian ini adalah bertujuan untuk mengetahui profil konflik dan dampak konflik sosial terhadap implementasi pendidikan agama dan keagamaan, bagaimana kebijakan pemerintah menyikapi dampak sosial terhadap implementasi pendidikan agama dan keagamaan serta bagaimana implementasi pendidikan agama di Provinsi Papua, yang pernah mengalami konflik sosial.

Penelitian ini dilaksanakan pada SMA Muhammadiyah dan Stikom tepatnya terletak di Jin. Abepantai No. 25 Kampung Tanah Hitam Kelurahan Awiyo Kecamatan Abepura Provinsi Papua. Penelitian ini bersifat kualitatif, teknik pengumpulan menggunakan data sekunder dan data data primer melalui wawancara mendalam dan obesrvasi.

\section{HASIL PENELITIAN}

\section{A. Profil Konflik}

Konflik yang terjadi di Provinsi Papua Kecamatan Abepura Kelurahan Awiyo disebabkan oleh ketidakseimbangan dalam bidang ekonomi misalnya kesenjangan status sosial, kurang meratanya kemakmuran dan akses yang tidak seimbang terhadap sumberdaya. Kondisi ini kemudian menimbulkan masalahmasalah seperti pengangguran, kemiskinan, prasangka. Masing-masingtingkat yang dimaksud saling berkaitan membentuk suatu mata rantai yang memiliki potensi, kekuatan untuk terjadinya kerusuhan ataupun konflik. Konflik masalah agama tidak pernah terjadi, yang ada adalah konflik antar etnis di Kecamatan Abepura Kelurahan Awiyo.

Demikian pula belum terjadi konflik yang menyebabkan sarana pendidikan agama dan keagamaan tetap dilindungi oleh masyarakat dan pelaksanaan belajar mengajar tidak terganggu dan tetap berjalan seperti biasanya vvalaupun terjadi konflik. Konflik yang terjadi di daerah tersebut faktor penyebabnya di awali 


\section{Mu 'jizatullah}

dengan isu-isu atau prasangka kemudian mendorong pertentangan yang berskala kecil.

\section{B. Profil Pendidikan Agama}

Gambaran pendidikan agama dan keagamaan di Provinsi Papua:

\section{Yapis (Yayasan Pendidikan Islam)}

Yayasan ini didirikan pada tanggal 15 Desember 1968 atau bertepatan dengan tanggal 24 Ramadhan 1388 H. Latar belakang didirikannya Yapis ini diantaranya adalah karena adanya kesadaran dari tokoh-tokoh Islam setempat, bahwa keberadaan umat Islam yang sudah lama dianut selama ratusan tahun, ternyata tertinggal jauh bila di bandingkan dengan perkembangan agama Kristen, bahkan pada masa penjajahan, umat Islam selalu mendapat tekanan dari pemerintah kolonial Belanda yang kebetulan beragama Kristen. Alasan lain didirikannya Yapis adalah adanya pemusatan pendidikan yang diserahkan kepada Zending dan misi yang diatur dengan Legere Onderwijs Subsidie Ordonantie (LOSO) untuk pendidikan Dasar, dan Melderbaar Onderwijs Subsidie Ordonantie (MOSO) untuk sekolah Lanjutan.

Semua sekolah pada waktu itu diurus oleh yayasan yang didirikan oleh Zending yaitu Yayasan Persekolahan Kristen (YPK), Yayasan Pendidikan Persekolahan Gereja Injil (YPPGI) dan yang didirikan oleh Misi Yayasan Advent yang didirikan oleh Advent. Umat Islam yang jumlahnya sudah cukup banyak belum memiliki lembaga pendidikan sendiri. Bila mereka akan menyekolahkan anaknya, maka umat Islam harus menyekolahkannya pada yayasan milik Kristen tersebut.

Padahal umat Islam memiliki komunisnya sendiri yang banyak terdapat di beberapa daerah seperti Raja Ampat, Fatagar, Patipi, Rumbati, Atiati, Kokas, Mamote, Babo dan Bintuni.

Di Merauke melalui benih-benih yang ditanam oleh para pejuang Republik yang diasingkan ke diguel/Tanah Merah seperti Suyuti Malik, Muhammad Hatta dll, komunitas Islam juga berkembang cukup banyak.

Jalan bagi berdirinya Yapis terbuka setelah Bupati Merauke, Drs. Anwar Ilmar dipindahkan jadi Bupati Jayapura. Anwar melanjutkan cita-citanya di Jayapura. Dengan dibantu oleh Salikin Soemowardaya sebagai Kepala Dinas P dan K Propinsi dan didukung tokoh-tokoh Islam Jayapura pda tanggal 15 Desember 1968, Yayasan Pendidikan Islam (Yapis) berdiri di Papua. 


\section{Mu 'jizatullah}

Pada waktu mendirikan Yapis, pemerintah daerah hanya mengizinkan satu yayasan saja untuk mewadahi sekolah-sekolah Islam di Papua. Oleh karena itu sekolah yang beraaungdi bawah Sekolah Muhammadiyah, sekolah Al Ma'arif dan sekolah Islam Iainnya semua bernaung dibawah bendera Yapis.

Sejak berdiri sampai sekarang Yapis telah memiliki sekolah Taman Kanakkanak sampai Perguruan Tinggi. Bahkan saat ini Yapis telah memiliki dua Sekolah Tinggi (STIE dan STAIS), saat ini telah berubah menjadi STAIN.

Kendati Yapis berpayung di lembaga pendidikan Islam, namun pada kenyataannya siswa atau murid yang belajar disana adajuga yang berasal dari agama lain seperti Kristen. Bagi siswa yang mengikuti pendidikan di tingkat dasar, menengah, maupun perguruan tinggi di Yapis sudah barang tentu mereka mengikuti pelajaran agama Islam. Dari proses pendidikan itu selanjutnya ada diantara mereka yang tertarik masuk Islam.

\section{HidayatuIIah}

Hidayatullah adalah lembaga pendidikan, dakwah dan kader. Pesantren yang didirikan tahun 1973 oleh (Aim) Abdullah Said di Balikpapan Kalimantan Timur ini, mulai melirik tanah Papua sejak awal tahun 1990. Sekarang dari 12 kota kabupaten yang terdapat di Papua, Hidayatullah telah menempatkan tenaga dainya disana. Tercatat hingga saat ini terdapat 200 muballigh Hidayatullah yang menyebar ke berbagai pelosok Papua.

\section{Muhammadiyah}

Muhammadiyah adalah lembaga dakwah dan pendidikan. Muhammadiyah mulai berdiri di Papua sejak tahun 1967. Sebagaimana halnya dengan lembaga pendidikan Ma'arif milik Nahdlatul 'Ulama (NU), seluruh sekolah-sekolah Muhammadiyahjuga berada di bawah bendera Yapis. Bahkan ditingkat Pimpinan Umum Yayasan, kedua organisasi yang kerap saling "eker-ekerang" ini, di Papua justru sebaliknya. Mereka bisadikatakan mesradan saling menjalin kerjasama, setidaknya di Iingkungan Yapis. Maka bila pimpinan Yapis dijabat oleh Muhammadiyah, maka wakilnya otomatis dari NU, begitupun sebaliknya. Dalam hal kekompakan tokoh kedua pucuk pimpinan NU- Muhammadiyah ini yakni Abdurrahman Wahid dan SyafiT Ma'arif mengaku kagum dengan semangat ukhuwah ummat Islam di Papua, khususnya di Yapis.

Sekolah SMA Muhammadiyah didirikan pada tahun 1973 yang terletak pada Jalan Abepantai No. 25 Kampung Tanah Hitam Keluarahan Awiyo Kecamatan Abepura. Motivasi sehingga sekolah tersebut didirikan yaitu untuk 


\section{Mu'jizatullah}

mewujudkan misi Muhammadiyah yaitu Amal MakrufNahi Mungkar melalui sekolah atau pendidikan tersebut.

SMA Muhammadiyah didirikan oleh H. Hasan Kasmali, mantan Ketua Pimpinan Muhammadiah Wilayah Papua, dan Mantan Kepala Kantor Departemen Agama Papua. Hasil Wawancara yang diperoleh dari Kepala Sekolah SMA Muhammadiyah Papua yaitu Drs. Dahlan Zein dan Ketua Stikom, Drs. H. M. Arifin, MM menunjukkan bahwa pada sekolah SMA Muhammadiyah terdapat siswa yang beragama Kristen Katolik, Kristen Protestan dan Hindu. Sementara disisi lain Sekolah Tinggi Komunikasi (Stikom) yang barada di bawah naungan Muhammadiyah memiliki mahasiswa yangterdiri dari multikultural, dan multiagama yaitu agama Kristen Katolik, Kristen Protestan dan agama Islam. Adapun etnis mahasiswa tersebut dapat mewakili semua etnis yang ada di Propinsi Papua, ditambah dengan suku Bugis-Makassar dan Jawa. Data terakhir yang diperoleh dari Kepala Tata Usaha SMA Muhammadiyah dan Stikom menunjukkan bahwa $90 \%$ diantara mahasiswa pada peguruan Stikom terdiri dari non muslim atau Kristen Katolik.

Dari data tersebut menunjukkan bahwa pendidikan SMA Muhammadiyah dan Stikom masuk dalam kategori pendidikan berwawasan multikultural sebab pendidikan tersebut telah membentuk sikap siswa dan mahasiswa untuk menghargai keragaman agama dan budaya dengan mengajarkan tentang berbagai pendapatan dalam tata hubungan sosial tanpa membedakan strata sosial dalam masyarakat dan pendidikan tersebut mempunyai pemahaman bahwa seluruh kelompok etnik, agama, dan budaya masyarakat Indonesia memiliki hakyang sama untuk mencapai prestasi terbaik di bangsa ini sebab menurut $\mathrm{H}$. A. R Tilaar pendidikan multikultur hanya untuk meningkatkan penghargaan siswa terhadap keragaman etnik, agama dan budaya masyarakat bukan berarti siswasiswa SMA Muhammadiyah dan Stikom Muhammadiyah yang beragama selain Islam hams mendapatkan pelajaran sesuai dengan agama masing-masing akan tetapi siswa selain agama Islam diarahkan untuk mempunyai sikap agar menghargai keragaman agama dan budaya.

Sebagai informasi perbandingan sebagaimana hasil wawancara dengan Yamus Pangaribuan, SH, MM. Kabid PAK (Pendidikan Agama Kristen) menyatakan bahwa sekolah favorit Kristen di Papua yang dikenal dengan nama Kalam Kudus, kurikulum pada sekolah tersebut adalah KTSP, yang berasaskan agama Kristen tetap mengajarkan pendidikan agama Kristen bagi semua siswa tanpa melihat perbedaan agama didalamnya, sama halnya dengan SMA Muhammadiyah yang berasaskan Islam tetap mengajarkan pendidikan agama 


\section{Mu 'jizatullah}

Islam tanpa melihat perbedaan agama. Namun demikian SMA Muhammadiyah dan Sekolah Kalam Kudus tetap memberi dukungan terhadap pengembangan dan pembinaan multikulturalisme baik dalam penyediaan fasilitas belajar dan layanan administrasi.

Hasil wawancara yang diperoleh dari Wakil Kepala Sekolah menyatakan bahwa pada tahun 1973 sekolah SMA Muhammadiyah dan Perguruan Muhammadiyah tersebut adalah berada di bawah naungan Yapis Abepura. Kemudian pada tahun 2000 sekolah tersebut sudah berada di bawah naungan SMA Muhammadiyah. Hal ini terjadi karena Muhammadiyah menginginkan agar mempunyai suatu lembaga dakwah tersendiri melalui perguruan tersebut namun kerjasama dengan Yapis (Yayasan Pendidikan Islam) masih tetap terjalin dengan baik, hal ini menunjukkan bahwa guru-guru yang mengajar pada Perguruan Muhammadiyah adalah merupakan bagian dan tenaga pengajar pada Yapis.

\section{d. Pendidikan Agama Kristen}

Pendidikan agama Kristen yang terkenal di Papua adalah Kalam Kudus. Sekolah tersebut terdiri dari TK, SMP, dan SMA. Siswanya terdiri dari beragam agama dan budaya yang terdiri dari $90 \%$ pendatang yang didominasi oleh orang-orang Cina sementara penduduk pribumi hanya sekitar $10 \%$. Sama halnya tenaga pengajar atau guru yang mengajar pada sekolah tersebut terdiri dari multikultur dan multiagama.

Sekolah Kalam Kudus yang dikenal dengan sekolah favorit di Provinsi Papua mempunyai sarana dan prasarana yang cukup lengkap sama halnya dengan sekolah Yapis (Yayasan Pendidikan Islam) yang dikenal favorit di Kota Jayapura. Namun demikian SMA Muhammadiyah dikenal berwawasan multikultural sebab siswanya terdiri dari beragam agama dan etnis.

Pada awalnya Sarana sekolah Kalam Kudus disponsori oleh Misi dari Belanda, Canada dan Eropa akan tetapi saat ini bantuan dana tersebut sudah dihentikan karena peraturan Menteri Keuangan karena semua bantuan keuangan dari luar negeri harus melewati Menteri Keuangan. Di sisi lain mengenai pembayaran SPP sangat tergantung pada kesepakatan Komite Sekolah.

\section{Pendidikan Keagamaan}

Lembaga Keagamaan di Kota Jayapura belum memadai, lembaga tersebut belum mempunyai Fasilitas sarana dan Prasarana tertsendiri, status masih menumpang. seperti lembaga Keagamaan.MajelisTalim Al Fitrajaya Asri Entrop 
Abepura, Sama halnya dengan lembaga Keagamaan Aisyiah status masih menumpang di sekolah Taman Kanak- kanak Aisyiah. Menurut Ketua Majelis Taklim al Fitra kegiatan pada Majelis Taklim tersebut cukup efektif, beberapa kegiatan tersebut diantaranya belajar mengaji dan tadarus, bagi yang belum mampu membaca Al Quran diberi bimbingan tersendiri. Pengajian dengan menghadirhan ulama dari pesantren Hidayatullah dan belajar Keterampilan. Pendidikan Keagamaan disini mengarah pada sikap toleransi antara ummat beragama.

Berbeda halnya dengan Lembaga Keagamaan Kristen, Pendidikan Keagamaan tempatnya di gereja, hasil wawancara dengan pendeta Herman Saud, MTH Beliau adalah salah satu tokoh agama Kristen di kota Jayapura mengatakan bahwa lembaga keagamaan yaitu Gereja Kristen Injil (GK.I) dikota Jayapura mulai di bangun pada tanggal 5 Februari 1956. Kegiatannya tidak jauh berbeda dengan lembaga keagamaan Majelis Taklim hanya saja misi para pendeta Gereja Kristen Injil lebih kuat karena mereka mendapat bantuan dana dari luar negeri seperti Kanada dan Australia akan tetapi akhir-akhir ini bantuan tersebut sudah tidak ada lagi sehingga kegiatan misi Kristen sudah mulai berkurang.

Hasil wawancara dengan salah satu unsur ketua Gabungan Organisasi Wanita: Ibu Athira mengatakan bahwasanya peranan Majelis Taklim yang ada di Propinsi Papua sangat besar dalam mewujudkan kerukunan antar ummat beragama di Kelurahan Awiyo. Wujud dari toleransi tersebut di kalangan umat Islam diantaranya mengadakan pertemuan dengan sesama warga dalam membahas atau mengantisipati masalah kerukunan beragama.

Melihat kondisi masyarakat yang menjauh dari ajaran agama maka, peranan sarana keagamaan lebih menitik beratkan pada pengembangan dan pemahaman nilai-nilai agama. Dan semakin derasnya arus globalisasi yang menyebabkan ummat beragama dipengaruhi dari luar maupun dari dalam oleh karena itu, lembaga keagamaan seperti majelis taklim hadir dengan suatu komitmen menyelamatkan agama dari berbagai pengaruh tersebut dan berupaya mengembalikan masyarakat kepada ajaran agama yang sebenarnya berdasarkan tuntunan agama masing-masing. Pendidikan keagamaan selama ini belum menunjukkan pengaruh yang dominan dikalangan ummat beragama kliususnya di Kelurahan Awiyo. Oleh karena itu lembaga keagamaan berperan menjaga hubungan baik diantara semua agama yang ada di kelurahan Awiyo karena sarana dan prasarana penunjang belum memadai. Oleh karena itu, pendidikan 


\section{Mu 'jizatullah}

keagamaan yang dilakukan haruslah atas koordinasi dan partisipasi dengan masyarakat sekitar, pemerintah daerah setempat dan dinas-dinas atau instansi terkait karena dalam menginternalisasikan nilai-nilai agama kedalam lapisan masyarakat fluralistik perlu mempelajari kondisi dimana masyarakat itu berada sehingga tidak terjadi hubungan yang tidak harmonis. Karena untuk mengajak ummat kejalan yang benar menurut agama masing-masing perlu pendekatan secara persuasif.

Melihat problematika ummat beragama selama ini maka yang perlu dipertajam oleh lembaga keagamaan adalah pemahaman agama secara keseluruhan yang didalamnya mengandung perundang-undangan, peraturan dan bimbingan.

\section{B. Dampak Konflik Terhadap Pendidikan Agama dan Keagamaan}

Dalam konteks penelitian ini dampak konflik diartikan sebagai pengaruh atau akibat yang ditimbulkan oleh konflik sosial, baik yang bersifat merugikan (dampak negatif) maupun yang bersifat menguntungkan (dampak positif) terhadap pelaksanaan pendidikan agama dan keagamaan di Papua Kecamatan Abepura Kelurahan Awiyo.

Sebelum hadir SMA dan Stikom Muhammadiyah yang berasaskan Islam di Abepura. Dampak negatifnya adalah polarisasi yang terus terjadi, ketidak percayaan dan permusuhan diantara kelompok yang berbeda dalam masyarakat. Prasangka masyarakat Abepura bahwa konflik sosial disebabkan oleh ketidakadilan pemerintah dalam bidang ekonomi terhadap penduduk pribumi dan pendatang mengenai: Kebutuhan pokok, ketidakadilan HAM, kurangnya toleransi multikultur dan multiagama, partisipasi dan otonomi sering menjadi inti pembicaraan. Kita dapat melihat pada pendidikan agama dan keagamaan yang berada di bawah naungan Muhammadiyah seharusnya memberikan kesempatan kepada semua siswa untuk dapat mempelajari pendidikan agama sesuai dengan agama masing-masing.

Dampak positifnya adalah kehadiran SMA dan Stikom Muhammadiyah dapat merubah masyarakat disekitar Kelurahan Awiyo Kecamatan Abepura dapat meningkatkan komunikasi dan saling pengertian antar kelompok yang mengalami konflik, mengusahakan toleransi antar beragama dan dapat menerima multikultur dan agama yang ada di wilayah tersebut melalui pendidikan agama dan keagamaan. Konsep pendidikan multikultur pada SMA dan Stikom Muhammadiyah adalah pendidikan multikultur yang berkonotasi. 
Pendidikan tentang keragaman budaya, atau pendidikan untuk membentuk sikap menghargai keragaman budaya. Siswa tidak dapat mempelajari pendidikan agama sesuai dengan agama masing-masing.

Satu contoh yang dapat kita lihat pada perguruan Muhammadiyah baik SMA maupun Perguruan Tinggi telah menciptakan hubungan komunikasi dan toleransi antar ummat beragama sehingga kehadiran pendidikan yang dimiliki oleh Muhammadiyah telah menciptakan satu kedamaian dan mengimplementasikan pendidikan multikultur di Propinsi Papua. Meskipun pada sekolah tersebut belum sempat mendapatkan pelajaran pendidikan multikultural secara teori. hal ini sangat menarik diteliti sebab Perguruan Muhammadiyah yang berasaskan Islam tetapi disisi lain tidak ada aturan untuk melarang agama selain Islam untuk masuk pada lembaga pendidikan tersebut, semua agama dan etnis boleh masuk pada lembaga tersebut dan yang lebih menarik lagi adalah semua siswa dan mahasiswa yang masuk pada pendidikan tersebut harus mengisi formulir dengan menyatakan secara tertulis bahwa siap untuk belajar pendidikan agama Islam tanpa membedakan agama.

Selanjutnya peranan Perguruan Muhammadiyah baik tingkat SMA maupun perguruan tinggi yang berada pada daerah tersebut adalah membantu pihak-pihak yang mengalami konflik untuk tidak larut dalam berbagai masalah dan isu, dan mengajarkan mereka untuk melakukan negosiasi yang tepat berdasarkan kepentingan bersama, melancarkan proses pencapaian kesepakatan yang menguntungkan semua pihak dan membantu pihak-pihak yang mengalami konflik untuk mengidentifikasi bersama kebutuhan mereka yang tidak terpenuhi dan menghasilkan pilihanpilihan untuk memenuhi kebutuhan-kebutuhan itu, pihak-pihak yang mengalami konflik dapat mencapai kesepakatan untuk memenuhi kebutuhan dasar semua pihak.

Selanjutnya dampak konflik terhadap pendidikan agama tidak berpengaruh terhadap keadaan gedung ataupun ruang belajar karena konflik yang terjadi di Kelurahan Awiyo Kecamatan Abepura Propinsi Papua hanya konflik sosial yang tidak berdampak pada proses belajar mengajar dan fasilitas pendidikan.

Sama halnya dengan dampak konflik terhadap pendidikan keagamaan tidak berpengaruh kepada sarana dan prasarana pendidikan keagamaan karena konflik yang terjadi di Papua lebih kepada konflik masalah kecemburuan sosial dalam 
bidang ekonomi antara penduduk pribumi dan pendatang tidak seperti yang terjadi pada daerah-daerah lain.

Lembaga keagaman yang berada di Kelurahan Awiyo Kecamatan Abepura tersebut adalah Aisyiah yang terletak di jalan Gerilyawan No. 49 Kelurahan Awiyo Kecamatan Abepura. Lembaga keagamaan tersebut belum mempunyai sarana tersendiri, saat ini masih bergabung di Taman Kanak-Kanak Aisyiah.

Pendidikan keagamaan di organisasi tersebut dibina oleh majelis tablig, diantara kegiatan yang dilakukan adalah pengajian bulanan bersama majelis taklim Aisyiah bekerja sama dengan Majelis Taklim NU. Ulama dan Dai yang bertugas secara tetap memberikan pendidikan keagamaan adalah Ibu Chalehah N. Pasanden dan Ibu Sutina Suthardi S.Pd.I yang berpedoman pada Buku Putusan Tarji Muhammadiyah. Adapun sumber dananya dari swadaya organisasi. Jumlah anggotanya sebanyak 60 orang.

\section{Kebijakan Pemerintah dalam Pendidikan Agama dan Keagamaan}

Kebijakan pemerintah terhadap SMA Muhammadiyah dan STIKOM salah satu diantaranya adalah memberikan bantuan ruang kelas baru sebagaimana kita dapat lihat pada gambar di bawah. Selain itu bantuan proyek tiap tahun yang diberikan kepada sekolah tersebut. Diantaranya bantuan komputer, Laptop dan internet. Selain bantuan pemerintah terhadap tenaga kependidikan (guru bidang studi) juga menyediakan buku-buku perpustakaan cukup signifikan.

Kebijakan pemerintah terhadap pendidikan keagamaan yaitu pendidikan usia dini di bawah naungan pendidikan luar sekolah yang diadakan oleh Aisyiah. Selanjutnya bantuan pemerintah setiap tahun pada kegiatan tingkat nasional seperti workshop dan pesertanya terdiri dari organisasi-organisasi Islam.

\section{Implementasi Pendidikan Agama dan Keagamaan}

Implementasi dalam konteks penelitian ini adalah implementasi pendidikan agama yang berarti pelaksanaan pendidikan agama, yang mencakup batasan pengertian:

a. Pendidikan agama yang dilaksanakan pada sekolah umum dalam hal ini adalah SMA Muhammadiyah yang berada di Kelurahan Awiyo Kecamatan 
Abepura Propinsi Papua dan Perguruan STIKOM Jurusan Komunikasi dan Humas (Hubungan Masyarakat).

b. Pendidikan keagamaan dilaksanakan dengan masyarakat secara non-formal dalam hal ini lembaga keagamaan Aisyiah yang barada di Kelurahan Awiyo Kecamatan Abepura Propinsi Papua.

\section{Aspek Input}

- SMA Muhammadiyah terdiri dari Jurusan yaitu IPA dan IPS. Jumlah siswa pada tahun 2005 - 2006 sebanyak 223 orang. Pada tahun 2006 - 2007 jumlah siswa secara keseluruhan sebanyak 258 orang.

- Jumlah guru sebanyak 20 orang yang terdiri dari guru tetap dan guru honorer. Satu orang diantaranya beragama Kristen yaitu guru Olahraga. Sedangkan tenaga Administrasi sebanyak 1 orang.

- Alat pembelajaran yang terdapat di SMA Muhammadiyah terdiri dari Laboratorium sebanyak 2 ruangan yaitu Laboratorium IPA dan Laboratorium Komputer. Ruang Perpustakaan sebanyak 1 ruangan. Ruang kelas terdiri dari 7 rombongan dan alat-alat pembelajaran multimedia diantaranya TV, OHP, Laptop, Internet, Edukasi Net. Buku pegangan ditentukan oleh guru bidang studi masing-masing.

- Kurikulum yang digunakan untuk kelas X adalah KTSP 2007/-2008. untuk kelas XI dan XII adalah KBK (Kurikulum Berbasis Kompetensi) 2004.

- Buku paket pendidikan agama Islam mendapat bantuan dari Departemen Agama.

Menurut hasil wawancara dengan Kepala Bidang Pendidikan Agama Kristen, Yamus Pangaribuan, SH, MM; Informasi perbandingan dengan sekolah Kalam Kudus sejak tahun 2008 tidak mendapatkan buku paket pendidikan agama Kristen dari Kanwil Departemen Agama Papua sejak dikeluarkannya Kebijakan Pemerintah terhadap pendidikan agama yaitu Kepres Sekolah Umum dan Madrasah pendidikan agama dari SD sampai Perguruan Tinggi tidak ada lagi alokasi wajib belajar 9 tahun. Berlaku untuk khusus Kabid Pendidikan Agama Kristen Departemen Agama karena sudah diakomodir oleh Departemen Pendidikan Nasional. 


\section{Mu'jizatullah}

\section{- Proses Belajar Mengajar}

Proses pengelolaan institusi sekolah secara desentralistik dan luwes dengan melihat buku pegangan yang ditentukan oleh guru mata pelajaran. Selanjutnya teknik proses belajar mengajar pada umumnya yang dilakukan guru di sekolah lebih kepada metode ceramah dan diskusi dalam hal ini guru dan murid sama-sama aktif di dalam kegiatan belajar mengajar. Adapun proses pelaksanaan evaluasi pada sekolah tersebut adalah secara umum baik tertulis maupun lisan. Kemudian pertanggungjawaban sekolah pada pejabat pemerintah terkait dan organisasi Muhammadiyah dilaporkan setiap semester dan setiap tahun.

\section{Aspek Output}

Kelulusan UAN pada SMA Muhammadiyah untuk tahun 2005-2006 adalah untukjurusan 1PA $100 \%$ denganjumlah siswa sebanyak 10 orang dengan NEM tertinggi 18,67 dan jurusan IPS tertingi 79,63\% denganjumlah siswa 55 orang dengan NEM tertinggi 18,83 sedangkan untuk tahun 2006 - 2007 kelulusan UAN untuk jurusan IPA $75,00 \%$ dengan jumlah siswa 33 orang dan NEM tertinggi 26,27 dan jurusan IPS $69,14 \%$ dengan jumlah siswa sebanyak 81 orang dan NEM tertinggi 22,75.

Keadaan presentase pencapaian efisiensi out put tahun 2005--2006 untuk jurusan IPA adalah $18,67 / 60 \times 100 \%=31 \%$ sedangkan untuk jurusan IPS adalah $18,83 / 60 \times 100 \%=31 \%$. Pada tahun 2006-2007 pencapaian efesiensi output untuk jurusan IPA adalah $26,27 / 60$ x $100 \%=44 \%$ sedangkan untuk jurusan IPS adalah $22,75 / 60 \times 100 \%=38 \%$.

Keadaan pencapaian efisiensi out put pada tahun 2005-2006 nilai rata-rata NEM untuk jurusan IPA yaitu 16,72 sedangkan untukjurusan IPS nilai rata-rata NEM yaitu 15,37. Pada tahun 2006-2007 nilai ratarata NEM adalah 20,20 sedangkan untukjurusan IPS nilai rata-rata NEM yaitu 17,08 .

Dari data tersebut menunjukkan bahwa presentase kelulusan siswa pada SMA Muhammadiyah tidak produktif karena presentase kelulusan dari tahun 2005-2006 ke tahun 2006-2007 mengalami penurunan sebagaimana data tersebut di atas. Sedang presentase pencapaian nilai rata-rata NEM menunjukkan peningkatan karena nilai rata -rata NEM dari tahun 2005-2006 ke tahun 2006-2007 mengalami peningkatan. Data 
yang diperoleh dari Kasubag TU Stikom, Bapak Abd. Rauf, menyatakan bahwa pada tahun 2006 jumlah mahasiswa sebanyak 570 orang yang terdiri dari agama Kristen 416 orang, Katolik 84 orang dan agama Islam 70 orang. Selanjutnya pada tahun 2007, jumlah mahasiswa 296 orang yang terdiri dari Kristen Protestan 238 orang, Kristen Katolik 39 orang dan Islam 19 orang. dari data tersebut penulis dapat menyimpulkan bahwa presentase jumlah mahasiswa dari tahun 2006 ke tahun 2007 mengalami penurunan yang cukup signifikan.

Hasil wawancara dengan Bapak Abdul Malik Laha, Bendahara Stikom mengatakan bahwa presentase jumlah mahasiswa menurun disebabkan banyaknya mahasiswa yang belum mampu membayar uang kuliah. Kendala yang dihadapi adalah pembayaran uang kuliah yang sering terlambat. Namun demikian tidak ada sikap yang keras kepada mahasiswa yang belum dapat menyelesaikan pembayaran uang kuliah.

Berbeda dengan hasil wawancara dengan Ibu Athira yang mencoba menganalisa menurunna jumlah presentase mahasiswa disebabkan karena mereka menyadari bahwa perguruan tersebut mempunyai misi dakwah untuk menyebarkan Islam dan jelas semua mahasiswa dapat terpengaruh dengan misi tersebut. Terbukti beberapa mahasiswa selain agama Islam telah berhasil masuk ke dalam agama Islam. Sehingga misi kristenisasi terus berjalan, salah satu cara untuk menjalankan misi tersebut dengan cara menggiring mahasiswa untuk tidak memasuki perguruan tinggi Stikom yang dikelola oleh Muhammadiyah.

Berdasarkan hasil pengamatan langsung yang dilakukan oleh penulis menunjukkan bahwa Perguruan Islam yang berada di bawah naungan Muhammadiyah berwawasan multikultural. Kelompok etnik mayoritas harus menghargai kelompok minoritas untuk mengembangkan kreatifitas dan budayanya. Toleransi terhadap multikultural, agama dan etnik sangat terlihat pada lembaga pendidikan tersebut. Pada sekolahsekolah tersebut telah terbangun tatanan kehidupan yang seimbang, tidak terjadi proses diskriminasi atau pembedaan status. Mampu membangun toleransi terhadap perbedaan atau menghargai kebebasan satu sama lain dalam rangka membangun suasana dan visi kehidupan bersama secara wajar dan lebih baik demi terwujudnya masyarakat yang damai. 
Mu 'jizatullah

Sekolah Tinggi Komunikasi tersebut dapat mengaplikasikan ilmu komunikasinya dengan baik karena telah diorentasikan pada pengembangan, penerimaan dan penghargaan terhadap pluralitas dan multikulturalitas nilai dan norma dalam masyarakat, dapat berkomunikasi dan berinteraksi dengan memeliharakeseimbangan dengan mengedepankan nilai-nilai toleransi dan sikap saling menghargai dan sating menghormati antar agama dan budaya yang cenderung melahirkan sikap ekstrim di tengah kehidupan kita sehingga melalui pendidikan SMA Muhammadiyah dan Stikom dapat meredam konflik sosial berbasis agama dan etnis.

\section{PENUT UP}

\section{Kesimpulan}

1. Gambaran konflik yang terjadi di Papua adalah konflik etnik di karenakan kecemburuan sosial yang berhubungan dengan masalah ekonomi dan konflik ingin merdeka keluar dari NKRI.

2. Dampak konflik sosial terhadap Implementasi Pendidikan Agama dan Keagamaan di Kelurahan Awiyo, Kecamatan Abepura, Kota Jayapura, Provinsi Papua tidak berpengaruh terhadap kegiatan belajar mengajar ataupun kegiatan keagamaan.

3. Kebijakan pemerintah terhadap implementasi pendidikan agama dan keagamaan tetap dilakukan sesuai dengan undang-undang dan kemampuan sehingga pemerintah memberikan batuan kepada sekolah sesuai dengan anggaran daerah.

4. Implementasi pendidikan agama dan keagamaan berjalan secara normatif dan tidak ada dampak terhadap implementasi pendidikan agama dan keagamaan di kecamatan Abepura dan Hamadi karena konflik yang terjadi dikarenakan kecemburuan sosial.

\section{Rekomendasi}

1. Hendaklah pemerintah mengantisipasi agar konflik tidak terjadi lagi dengan memanfaatkan fasilitas yang ada seperti lembaga keagamaan dan dewan adat Papua.

2. Perlunya peningkatan sarana dan prasarana terhadap SMA Muhammadiyah dan Stikom karena sekolah tersebut sangat berperan untuk mewujudkan wawasan multikultural terutama di dunia pendidikan. 
Mil jizatullah

\section{DAFTAR PUSTAKA}

Abdullah, Taufik (ed) 1986. Agama dan Perubahan Sosial. CV. Rajawali, Jakarta.

Ali, Athwa, 2004. Islam atau Kristenkah Agama Orang Irian? Pustaka Da'i, Jakarta

Anwar, Dewi Fortuna, 2005. Konflik Kekerasan Internal: Tinjauan Sejarah, EkonomiPolitik, dan Kebijakan di Asia Pasifik. Yayasan Obor Indonesia, LIPI, (LESMACNRS),KITLV, Jakarta.

Azra, Azyumardi. Pendidikan Islam dan Pengembangan SDMdalam Era Globalisasi, Makalah Seminar 27 Juli 1996.

Budiman, Arief. 1989. Sistem Perekonomian Pancasila dan Ideologi Ilmu Sosial di Indonesia. PT. Gramedia, Jakarta.

Campbell, Tom. 1994. Tujuh TeoriSosial: Sketsa, Penilaian, Perbandingan. Terj. F. Budi Hadirman, dari judul aslinya : Seven Theories of Human Society. Kanisius, Yogyakarta.

Craib, Ian. 1994. Teori-Teori Sosial Modern ; Dan Parsons sampai Habermas. Terj. Paul S. Baut dan T. Effendi, dari judul aslinya Modem Social Theory : From Parsons to Habermas. PT. Raja Grafindo Persada, Jakarta.

Darajat, Zakiyah. 1994. Ilmu Pendidikan Islam. Bina Rupa Aksara, Jakarta.

Departemen Agama. 1998. Manajemen Madrasah Aliyah PPAI Tingkat Menengah. Dirjen Bimbaga Islam.

Departemen Pendidikan dan Kebudayaan. 1983. Alat Penilaian Kemampuan Guru, Program AlatV-B, Komponen Dasar Kependidikan. Dirjen Dikti.

Djati Sidi, Indra. 2001. Menuju Masyarakat Belajar Menggagas Paradigma Baru Pendidikan. Paramadina, Jakarta

Fajar, A. Malik. 1998. Madrasah dan Tantangan Modemitas. Mizan, Bandung.

Irfing M Zeitting. 1998. Memahami Kembali Sosiologi. Gajah Mada, University Fress

Koentjaraningrat. 1980. Manusia dan Kebudayaan di Indonesia. Djambatan, Jakarta.

Langgulung, Hasan. 1998. Asas-Asas Pendidikan Islam. Radar Jaya Offset, Jakarta. 


\section{Mu'jizgtullah}

Lauer, Robert H. 1993. Perspektif Tentang Pembahan Sosial. Terj. Alimandan, dari judul aslinya: Perspective on Social Change. PT. Rineka Cipta, Jakarta.

Mannheim, Karl. 1985. Sosiologi Sistematis. Terj. Soerjono Soekanto. CV. Rajawali, Jakarta.

Nasution, S. 1982. Berbagai Pendekatan dalam Proses Belajar Mengajar. BinaAksara, Jakarta

Ngadisa, 2003. Konflik Pembangunan dan Gerakan Sosial Politik di Papua. Pustaka Raja, Yogyakarta 